\section{Global Journal of Foreign Language Teaching}

Volume 8 , Issue 1, (2018) 35-44

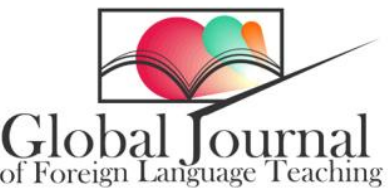

www.gjflt.eu

\title{
Ethnography of communication in ESP: Implications for medical practitioners as a community of practice
}

\author{
Abbas Behroozi*, Office of Foreign Affairs, Maragheh University of Medical Sciences, Moallem St., Maragheh \\ 5516773111, Iran.

\section{Suggested Citation:} \\ Abbas, B. (2018). Ethnography of communication in ESP: Implications for medical practitioners as a community \\ of Practice. Global Journal of Foreign Language Teaching. 8(1), 35-44.
}

Received from September 25, 2017; revised from November 06, 2017; accepted from January $02,2018$.

Selection and peer review under responsibility of Assoc. Prof. Dr. Jesus Laborda Garcia, Alcala University, Spain. ${ }^{\circ} 2018$ SciencePark Research, Organization \& Counseling. All rights reserved.

\begin{abstract}
Language is considered to be one of the significant set of practices in social world. Furthermore, ethnography of communication posits that language cannot be separated from its use in society. Hence, language can be taken as a means of interaction among members of a community of practice and reflection of their norms. Thus, the Leamers of English for specific purposes (ESP), as newcomers of a community of practice, need to be familiar with the linguistic codes of their field; and they constitute a community of practice where they exercise the English language they leam in work -related situations. Collecting data from different resources may help teachers and leamers of ESP courses realise what features of language their course should address. The present studyaims to highlight the contributions that ethnography of communication may make to identify the needs of the lea mers of English for medical purposes as a community of practice.
\end{abstract}

Keywords: ESP, ethnography of communication, community of practice, medical practitioners.

\footnotetext{
* ADDRESS FOR CORRESPONDENCE: Abbas, Behroozi, Office of Foreign Affairs, Ma ragheh University of Medical Sciences,
} Moallem St., Ma ragheh 5516773111, Iran. E-mail address: abehroozi 09@gmail.com / Tel.: +914-108-96-29 
Abbas, B. (2018). Ethnography of communication in ESP: Implications for medical practitioners as a community of Practice. Global Journal of Foreign Language Teaching. 8(1), 35-44.

\section{Introndırtion}

Over the last decades, using an English language to communicate either on everyday views or scientific issues has been nonstop and increasing. One significant area where English language has been employed is in conveying scientific information. Every year a great number of textbooks are published in English. Moreover, scholars from different science fields tend to publish their articles in English in the journals that require the authors to use English language as a medium. Besides many other socio-political factors, globalisation as a revolutionary change has contributed to the evolution of English language into a commonly used means of communication. Indeed, as this trend proceeds, individuals feel a need to learn English language to prove as an active member of the world on the whole and their community in particular.

It is generally said that social world involves a set of practices. And, language can be viewed 68(i)-36(0)-5(n)585 
Abbas, B. (2018). Ethnography of communication in ESP: Implications for medical practitioners as a community of Practice. Global Journal of Foreign Language Teaching. 8(1), 35-44.

\section{Ethnography of communication}

Simply put, communication denotes the way people interact and interchange information with each other; however, there appears to be much more to it when it is seen as a social practice like any other non-linguistic social practices as Bourdieu and Certeau observe. Certeau sees both linguistic and nonlinguistic social practices to have the same effects. While Bourdieu considers practice as a reproduction of social structure, Certeau sees it to be an act of agency. Bourdieu (1991, p. 89) observes:

Not only are linguistic features never clearly separated from the speaker's whole set of social properties (bodily hexis, physiognomy, cosmetics and clothing), but phonological (or lexical, or any other) features are never clearly separated from other levels of language; and the judgement which classifies a speech form as 'popular' or a person as 'vulgar' is based, like all practical predication, on sets of indices which never impinge on consciousness in that form.

This way of looking at language posits that language is not an abstract system detached from the community, which employs it rather to understand the true nature of language one should consider it in relation with other factors that affect not only the way it is used but also the variation that it undergoes with respect to the users. The term 'ethnography of speaking' and later 'ethnography of communication' was first proposed by Hymes $(1962,1964)$ to describe a novel approach to understanding language in use. In Hymes (1972, p. 52) view, ethnographies of communication must 'discover and explicate the competence that enables members of a community to conduct and interpret speech'.

According to the definition proposed by Hymes, it is clear that speech does not happen in vacuum. Rather, it is used in a specific context and 'when the meaning of speech styles are analysed, we real ise that they entail dimensions of participant, setting, channel and the like, which partly govern their meanings' (Hymes, 1989, p. 444). Clearly, if these elements inherent in speech be taken for granted, the presence of various types of speaking cannot be rejected. This may be one of the important contributions of the definition proposed by Hymes that promoted the description of the various ways of speaking which exist in the community (Sherzer \& Damell, 1972). In addition, this definition of speech includes both the means of speech that the speakers use, and also, the speech community that the speakers take part in.

This way of understanding and looking at language is very important because it assumes two inseparable aspects to be necessary for speech that is what the speakers utter and the communal context in which this speech happens. Thus, Hymes (1972) asserts that when talking about language, both aspects of speech should be considered equally and the terminology employed should reflect this. He further provides an explicit definition of means of speech as the features that enter into styles as well as the styles themselves' (Hymes, 1972, p. 446).

One important implication of taking speech economy and the means of speech to be equal is that frame utterances are meaningless outside a particular macro-social context and the relationships existing in the community. Plus, it shows that these utterances not only need to be decoded by the members, but also are of aesthetic judgement from the members. Hence, it can be claimed that the idea of speech community helps to maintain an understanding of language shared by a community and a way of variation in speech.

Farah (1998, p. 125) holds that Hymes's ethnography urges that 'the study of language must concern itself with describing and analysing the ability of the native speakers to use language for 
Abbas, B. (2018). Ethnography of communication in ESP: Implications for medical practitioners as a community of Practice. Global Journal of Foreign Language Teaching. 8(1), 35-44.

manner which is not only correct, but also appropriate to the socio-cultural context. This ability involves a shared knowledge of the linguistic code as well as of the socio-cultural rules, norms and values which guide the conduct and interpretation of speech and other channels of communication in a community'.

As a result of the changes that Hymes's ethnography of communication brought about, some theories and methods for exploring how language is embedded and enacted in discourse have been developed. One of the elements of ethnography of communication is the exploration of communicative competence in a speech community. Based on this conception, communicative language teaching approach to teaching language was introduced in the late 1960s. Since its inception, the approach has concerned itself with developing socio-cultural competence in the learners to make them know how to use language for different functions such as getting things done in different contexts.

ESP as a community is one of the offsprings of this approach to language teaching as in this kind of courses, the leamers constitute a community that share some common goals and attempt to acquire a language to be competent enough to use it in real situations to communicate the issues relating to their fields. In such a community, means of speech and speech economy, as two significant elements of ethnography of communication, can have some illuminating effects when it comes to analysing the learners needs. This is exactly where a social unit, i.e., speech community comes in to being. However, it should be noticed that by the speech community, Hymes does not just mean a community determined by common language, but rather it is a community that has common linguistic norms', a community sharing rules for the conduct and interpretation of speech, and rules for the interpretation of at least one linguistic variety' (Hymes, 1972, p. 54). According to this definition, ESP learner form a speech community since they share some rules and need to exercise these rules to stay an insider.

\section{Ethnography of communication in English for specific purposes}

It is said that ESP emerged as a branch of language teaching as a result of the spread of English as a global language, particularly, the dominant publication of academic articles and the recognition of language variation by use; and also, the basic properties of language use. Further, Paltridge and Starfield (2011) hold that that ethnography in ESP started following the interest in social context of language learning and teaching process. Considering that the ethnography of communication is concerned with the questions of what a person knows about appropriate pattems of language use in his or her community and how he or she learns about it' (Farah, 1998, p. 125), it can be said that since in ESP courses the needs of the learners are addressed, these courses constitute a community with its own patterns of language and shared interests of the learners.

According to Gumperz (1964), every recognised speech community has a repertoire of language codes and ways of speaking that includes 'all varieties, dialects or styles used in a particular socially defined population and the constraints which govern the choice among them' (Gumperz, 1977). ESP learners' course has their own variety and styles and are exercised in a socially defined population. Ethnography of communication addresses the totality of this linguistic repertoire or patterned ways of speaking. Plus, it explores the 'relationships between speech systems and other aspects of language' (Keating, 2001, p. 289). Keating (2001, p. 289) further adds that 'identifying and recording this repertoire through observation of communicative behaviours and consultation with the members of the community is an important part of an ethnography of speaking as well as documenting contexts and appropriateness of use' . Indeed, any ethnography of communication provides descriptions of the purposes of the speech event, such as outcomes and goals in a speech community.

Keating (2001) holds that ethnographers of speaking attempt to identify recurrent communicative events and their components. They try to boldface everyday events across the speakers, and also, 'the relationship between these events and other aspects of society, describing attitudes and ideas about language use, the acquisition of competence in communicative events and linking the use of language 
with the constitution of society' (Keating, 2001, p. 289). There are a few studies on the relationships in ESP community. For instance, Boswood and Marriott (1994) tried to find out how an ESL/ELT teacher can make an ESP practitioner. They discovered that teachers as ESP practitioner trainers could unpack the complex relationship in ESP discourse community. They also managed to define various roles of ESP practitioners.

In another study, Northcott (2001) investigated the role of interactive learning contexts geared in the standardisation process of lecturing. The findings of their study showed that when the group was smaller and they shared more background knowledge, the lecturers could employ interactive lecturing contexts more positively. Lilis (2008) investigated ethnography from academic writing and found that ethnography may be used as method, methodology and deep theorising. According to the findings of the researcher, ethnography can be used as a method to analyse texts. As a methodology, ethnographer needs to be a participant observer in the text production as an ethnographer. In terms of using ethnography as a theorising, it tends to narrow the ontological gap between text and context through indexicality, which is a way to index a social context and orientations through writing; and also, to show how speakers or hearers respond to the text.

Two important modified ethnography studies have recently been carried out by Swales (1998) and Paltridge (2008). In one study, Paltridge (2008) performed a textography for the teaching and researching writing for an examination of the exegeses in the art and design, writing section of Chinese college English test and analysis of kinds of writing required for academic study. In another study, Swales (1998) introduced a textography in writing. The study combined text analysis with interview, observation, document analysis for university herbarium, language and computer centre. Both of these studies show that writing style is under the influence of different expectations brought up by different communities.

Therefore, it can be asserted that in every speech community, the term that has been displaced by the community of practice (Lave \& Wenger, 1991) has its own distinguishing features that affect the practice of language specific for the community. And, ESP leamers as a speech community or community of practice have their own needs and features that should be noticed.

\section{Community of practice}

As a displacement for speech community, the term 'community of practice' was first mentioned by Lave and Wenger (1991) in the early 1990s to denote a group of people who share a concern or a passion for something they do, and they try to do it better through interacting with each other on a regular basis (Wenger, 2006). The community of practice draws on some disciplines like sociology, anthropology and education and has something to do with practice theory. Indeed, for the community of practice, activity is a central issue that should be investigated in sociolinguistic analysis. However, as Gherardi, Nicolini and Odela (1998, p. 279) argue 'referring to a community of practice is not a way to postulate the existence of a new informal grouping or social system within the organisation, but is a way to emphasise that every practice is dependent on social processes through which it is sustained and perpetuated, and that learning takes place through the engagement in that practice.'

People with a shared knowledge come together and even if they are he terogeneous, they share a high degree of trust, sense of purpose and common values and understanding. Through sharing and developing knowledge, the members of such a community not only develop knowledge, but also develop themselves personally and professionally (Lave \& Wenger, 1991). Thus, a community of practice is 'a group of people informally bound together by shared expertise and passion for a joint enterprise'. (Wenger \& Snyder, 2000, p. 139) and later define this as 'groups of people who share a concern, a set of problems or a passion about a topic, and who deepen their knowledge and expertise in this area by interacting on an ongoing basis' (Wenger, McDermott \& Snyder, 2002, p. 4) and further later defines this as 'groups of people who share a concern, a set of problems or a passion about a 
Abbas, B. (2018). Ethnography of communication in ESP: Implications for medical practitioners as a community of Practice. Global Journal of Foreign Language Teaching. 8(1), 35-44.

topic, and who deepen their knowledge and expertise in this area by interacting on an ongoing basis' (Wenger et al., 2002, p. 4).

One of the main objectives of communities of practice is to share stories from their experiences and discuss skills and techniques related to their practice. This is of high significance since communities of practice are 'nurtured', 'fostered' or 'cultivated' as a strategy of formal knowledge management in and across organisations (Murillo, 2011). In such situations, both communities and community members can add or create knowledge. The members of a community may be developers, teachers, lawyers, doctors, academics and consultants who share, create and identify knowledge (Katzy \& Ma, 2002). Through this practice, community members develop common codes and language, share norms and values. Further, they carry out critical reflection and engage in dialogue with each other at a professional level.

In these communities, the members generate an environment where there are high levels of trust, shared behavioural norms, and mutual respect and reciprocity (Sharratt \& Usoro, 2003). They are in active process of intending to learn to become a full participant. Through this process 'newcomers become acquainted with the tasks, norms, values and principles of the community; and then, gradually increase their participation and involvement in community life' (Agrifoglio, 2015, p. 27). As Lave and Wenger (1991, p. 29) put it 'this social process includes, indeed it subsumes, the learning of knowledgeable skills'. Knowledge is crucial to keep the community members together, and also, it is a valuable resource for its members (Fang \& Chiu, 2010). Therefore, it is a motivating factor for joining communities and is a strategic property and a valuable resource for organisational growth and sustained competitive advantage (Miller \& Shamsie, 1996).

According to Wenger (1998), community of practice refers to three dimensions: The first dimension is joint enterprise that concerns what the community is about; however, it is not merely about shared goals rather it involves mutual accountability as well. Li et al. (2009) define it as a process in which people engage themselves in working together to achieve a common goal. The other is mutual engagement which stands for how it functions and the last dimension is shared repertoire which shows what capability the community produces.

As to the types of communities, Fischer (2001) distinguishes two types: The first type which is homogenous and comprises members from a single discipline is to be taken as a community of practice. However, the second type, which is heterogeneous in nature and brings people from multiple disciplines together, is termed as community of interest of community of communities. Drawing on this categorisation, Agrifoglio (2015, p. 36) holds that 'rather than a community of interest, members of communities of practice are practitioners; and thus, develop a shared repertoire of resources'. Wenger et al. (2002) also hold that there are different forms of communities based on the members' cultural background. According to them, communities are composed of people who have the same discipline or function and essentially are homogenous. In this regard, Wenger et al. (2002, p. 27) revise the features of a community of practice into 'domain of knowledge, which defines a set of issues, community of people who care about this domain and the shared practice that they are developing to be effective in their domain'.

Wenger et al. (2002) assert that domain, community and practice are three indispensable elements of any community of practice. According to the authors, domain refers to the area of knowledge that brings the community together and determines the set of issues that the members need to address. Hence, domain provides 'the common ground (i.e., the minimal competence that differentiates members from non-members) and outlines the boundaries that enable members to decide what is worth sharing and how to present theirideas' (L et al., 2009, p. 6).

The other important element that need be discussed here is practice. Wenger et al. (2002) take practice to be a set of shared repertoires of resources including tools, experiences, stories and ways of addressing recurring problems. To put it another way, practice is an empirical object and as 'the locus in which scholars study the activities of the practitioners' (Corradi, Gherardi \& Verzelloni, 2010, p. 268). 
Based on this perspective, it can be claimed that practice pronounces the knowledge concerning sitespecific work practice (Sole \& Edmondson, 2002); and thus, it is defined as 'doing and involves awareness and application of both explicit (language, tools, concepts, roles and procedures) and tacit (rules of thumb, embodied capabilities and shared worldviews) elements (Sole \& Edmondson, 2002, p. 20).

Scholars assume the concept of practice to have three interpretive labels. Brown and Duguid (1991) use 'practice-based standpoint'; while scholars like Raelin (1997) and Strati (2007) prefer 'work-based learning or 'practice-based learning' and Whittington (1996) takes it as 'what people do'. Whatever the label the point has, that practice entails activity oriented towards the goal of every single member and the community. And, the members of any community should apply the language and tools along with their shared worldviews to not only satisfy their own needs, but also help to improve their community. In this regard, ESP members constitute a community of practice as they are roughly homogenous with some shared goals and needs.

Thanks to the progress in technology today, there are a myriad of ways to collect information for the members of communities of practice. It can be argued that now a key factor for the success of communities is to employ technology to make organising, storing, and sharing information and knowledge easier and faster. In communities of practice like ESP, use of technology can provide the members with the chance of having access to a large body of information, concerning the language that need to use in their field, in a way that encourages them to actively engage in their community through making remarks and adding their own information. The members may also use shared electronic calendars or emails applications that link back to the other members of their community. Medical students as new comers of the community of medical practitioners are among those who take ESP, in this case, English for medical purposes (EMP) to acquire the language as the means to le arn the knowledge inherent in the course and later use that language to efficiently negotiate it with other members of their community or individuals from other communities that need benefit from the knowledge of their field. Ideally, they attempt to build a community of practice where they acquire and deepen their knowledge of the medium needed along with gaining expertise by interacting with each other.

\section{Shared needs of the community of medical practitioners}

Given that 'communities of practice are privileged sites for developing, maintaining and sharing knowledge' (Agrifoglio, 2015, p. 39), it can be argued that in such a community, needs of the members and the requirements for the newcomers to become a member need be identified. In these communities, members attempt to 'explore ideas, discuss situations and needs, and help each other solve problems, although they do not meet every day' (Agrifoglio, 2015, p. 26). Further, Wenger (2004) holds that in communities of practice, identity is not defined by a task; rather it is determined through an area of knowledge that needs to be explored and developed. And, to help acquire this knowledge and satisfy their needs, communities of practice 'produce abstractions, tools, symbols, stories, terms and concepts that reify something of that practice in a congealed form' (Wenger, 1998, p. 59).

Learners of ESP courses can be taken to constitute a community of practice, as they share some common ground of knowledge and goals of using English language, in their profession to communicate their knowledge to both insiders and outsiders. Indeed, like other communities of practice, members share a concern and passion for something and even more important than that they have the same domain of knowledge and shared practice which is crucial according to Agrifoglio (2015). Of course, an ESP class does not include a large number of people and because of being small, it is more homogenous; and thus, it is easier to manage in terms of identifying and analysing the needs; and also, providing suitable materials to satisfy the needs and also foster the exchange of knowledge. Agrifoglio (2015, p. 41) argues that 'within such a community, people share their experience and tacit knowledge in free flow, improving their abilities and skills, and fostering learning'. 
Abbas, B. (2018). Ethnography of communication in ESP: Implications for medical practitioners as a community of Practice. Global Journal of Foreign Language Teaching. 8(1), 35-44.

According to Brown and Duguid (1991), communities of practice are interstitial in nature and exist in the 'gaps' between work as defined, and the tasks that need to be done. Given this point, since ESP courses concern equipping learners with English language, to enable them to convey and share their knowledge regarding the defined work and workplace they will encounter, it is crucial to realise what the learners of ESP courses need to learn and how they will exercise them. It seems that one of the contributions the ethnography of communication has made is to provide new units of analysis from the language in use. Thus, ethnography of communication can contribute to identification of the language that ESP learners should address.

Nunan (1988) holds that needs analysis is a process of information gathering, which is done to learn why learners want to leam a language; and the outcome of this will be choosing the most relevant materials to make learners ready for the situations they will encounter. In the community of medical students, needs concem the doctor-patient communication, writing research article, presenting university lectures and other related activities. Ethnography of such communications reveal their main features as they are used and determines 'the needs for which a learner or group of learners requires a language' (Richards, Platt \& Platt, 1992, p. 242).

As a result of some events like evolution of English language into a global language and globalisation and its ramifications like medical tourism, like many other fields, English has become the de facto language of international medicine and being fluent in this language seems to be needed to get the essential medical and scientific information (Heming \& Nandagopal, 2012). Thus, it can be concluded that doctors, researchers and other practitioners in this field need to learn English language to teach, negotiate or publish their research work (Milosavljevic, 2008). It should be noticed that all these practitioners need to use English language within their community or people from other communities; hence, when designing their ESP courses, this crucial point should be taken into account. Doley (2010) suggests that medical English curriculum includes major English language skills, i.e., speaking, listening, writing and reading along with English grammar and medical/general vocabulary to satisfy students' need of communicative competence.

\section{Conclusion}

After Gumperz and Hymes (1964) initiated the discussions of linguistics conceming units such as speech event, speech situation and speech community, and probed into the possible relations, these units have with other 'components of speech use' (Sherzer \& Darnell, 1972, p. 550), attitudes toward language and language teaching experienced a revolutionary shift. One of the ramifications of such a shift was to exercise ethnography of communication in so-called speech communities to consider their background information, e.g., history, material artefacts, e.g., written means of communication, information about social organisation, e.g., associations patterns, legal information, e.g., social control about language use, common knowledge about the interpretation of language and language habits, beliefs about language use and data on the linguistics code, e.g., paralinguistic and non-verbal features (Saville-Troike, 1982).

Another ramification of ethnography of communication was the communicative approach to teaching language that required that language courses turn language learners into competent speakers. Drawing on this point, course designers considered the inclusion of features of the language that learners of language courses for specific purposes needed to acquire in the so-called ESP courses. Indeed, these courses provided the opportunity to accumulate resources, in this case, information concerning the language the learners of the course needed to master in order to learn what the learners need to acquire and how they are required to exercise and foster it in the future (Ardichvili, Page \& Wentling, 2003; Fang \& Chiu, 2010).

In EMP, as one of the subcategories of ESP, where medical students are the newcomers of a community of practice including doctors, nurses and other practitioners, shared needs of the learners are addressed. Since through different means along with ethnography of communication, the quality 
Abbas, B. (2018 
Abbas, B. (2018). Ethnography of communication in ESP: Implications for medical practitioners as a community of Practice. Global Journal of Foreign Language Teaching. 8(1), 35-44.

Katzy, B. R. \& Ma, X. (2002). Virtual professional communities-definitions and typology. In Proceedings of the International Conference on Concu rrent Enterprising ICE (pp. 311-318).

Keating, E. (2001). The ethnography of communication. In P. Atkinson, A. Coffey, S. Delamont, J. Lofland \& L. Lofland (Eds.), Handbook of ethnography (pp. 285-301). London, UK: Sage.

Lave, J. \& Wenger, E. (1991). Situated learning: Legitimate peripheral participation. Cambridge, UK: Cambridge University Press.

Li, L. C., Grimshaw, J. M., Nielsen, C., Judd, M., Coyte, P. C. \& Graham, I. D. (2009). Use of communities of practice in business and health care sectors: a systematic review. Implementa tion Science, 4(27), 1-9.

Lilis, T. (2008). Ethnography as method, methodology and deep theorizing: Closing the gap between text and context in academic research. Written Communication, 25(3), 353-388.

Miller, D. \& Shamsie, J. (1996). The resource-based view of the firm in two environments: The Hollywood film studios from 1936 to 1965. Academy of Management Journal, 39(3), 519-543.

Milosavljevic, N. (2008). Interrelationship between learning English language and students medical education. Srpskiarhiv za celokupno lekarstvo, 1366(7-8), 441-444.

Murillo, E. (2011). Communities of practice in the business and organization studies literature. Information Research, 16(1). Retrieved from http://informationr.net/ir/16-1/paper464.html

Northcott, J. (2001). Towards an ethnography of the MBA classroom: a consideration of the role of interactive lecturing styles within the context of one MBA programme. English for Specific Purposes, 20, 15-37.

Nunan, D. (1988). The learner-centered curriculum. Cambridge, UK: Cambridge University Press.

Paltridge, B. (2008). Textographies and the researching and teaching of writing. IBERICA, 15, 9-24.

Paltridge, B. \& Starfield, S. (2011). Research in English for specific purposes. In E. Hinkel (Ed.), Handbook of research in second language teaching and learning (pp. 106-121). London, UK: Routledge.

Raelin, J. A. (1997). A model of work-based learning. Organization Science, 8(6), 563-578.

Richards, J. C., Platt, J. \& Platt, H. (1992). Longman dictionary of language teaching and applied linguistics. London, UK: Longman.

Saville-Troike, M. (1982). The ethnography of communication: An introduction. Oxford, UK: Blackwell.

Sharratt, M. \& Usoro, A. (2003). Understanding knowledge-sharing in online communities of practice. Electronic Journal on Knowledge Management, 1(2), 187-196.

Sherzer, J. \& Darnell, R. (1972). Outline guide for the ethnographic study of speech use. In J. Gumperz \& D. Hymes (Eds.), Directions in sociolinguistics: the ethnography of communication (pp. 548-554). New York, NY: Blackwell.

Sole, D. \& Edmondson, A. (2002). Situated knowledge and learning in dispersed teams. British Journal of Management, 13(S2), 17-34.

Strati, A. (2007). Sensible knowledge and practice-based learning. Management Learning, 38(1), 61-77.

Swales, J. (1998). Textography: to ward a contextualization of written academic discourse. Research on Language and Social Interaction, 31(1), 109-121.

Wenger, E. (1998). Communities of practice: Learning, meaning and identity. Cambridge, UK: Cambridge University Press.

Wenger, E. (2004). Knowledge management as a doughnut: Shaping your knowledge strategy through communities of practice. Ivey Business Journal, 68(3), 1-8.

Wenger, E. (2006). Communities of practice: a brief in troduction. Retrieved from www.ewenger .com/theory/

Wenger, E. (2010). Communities of practice and social learning systems: the career of a concept. In C. Blackmore (Ed.), Social learning systems and communities of practice. Springer Verlag and the Open University.

Wenger, E., McDermott, R. \& Snyder, W. M. (2002). Cultivating communities of practice (1st ed.). Watertown, MA: Harvard Business School Press.

Wenger, E. \& Snyder, W. M. (2000). Communities of practice: The organizational frontier. Harvard Business Review, 78(1), 139-145.

Whittington, R. (1996). Strategy as practice. Long Range Planning, 29(5), 731-735. 